\title{
METABOLITES WITH ANTIOXIDANT AND PROTECTIVE FUNCTIONS FROM LEAVES OF VEGETABLE AMARANTH (Amaranthus tricolor L.)
}

\section{M.S. GINS1, V.K. GINS1, S.M. MOTYLEVA², I.M. KULIKOV², S.M. MEDVEDEV², V.F. PIVOVAROV ${ }^{1}$, M.E. MERTVISHCHEVA ${ }^{2}$}

${ }^{1}$ Federal Research Center for Vegetable Growing, Federal Agency of Scientific Organizations, 14, ul. Selektsionnaya, pos. VNIISSOK, Odintsovskii Region, Moscow Province, 143080 Russia, e-mail anirr@bk.ru (corresponding author);

2All-Russian Horticultural Institute for Breeding, Agrotechnology and Nursery, Federal Agency of Scientific Organizations, 4, ul. Zagor'evskaya, Moscow, 115598 Russia

ORCID:

Gins M.S. orcid.org/0000-0001-5995-2696

Gins V.K. orcid.org/0000-0002-7053-4345

Motyleva S.M. orcid.org/0000-0003-3399-1958

Pivovarov V.F. orcid.org/0000-0003-1350-5852

The authors declare no conflict of interests

Acknowledgements:

The research was carried out under the theme № 0575-2017-0001 supported by the program of Federal Agency of Scientific Organizations for bioresource collections

Received July 8, 2017

Mertvishcheva M.E. orcid.org/0000-0001-9126-747X

\begin{abstract}
Antioxidant metabolites of plant origin are able to regulate many physiological functions of the body and reduce the risk of developing chronic diseases caused by free radical oxidation. Vegetable plants are the most affordable source of essential antioxidant metabolites lack of which leads to a sharp decrease in resistance to environmental stresses. Amaranth (Amaranthus tricolor L.) is a promising food and medicinal plant. Variety Valentina (originated by V.K. Gins, P.F. Kononkov, M.S. Gins, AllRussian Research Institute of Breeding and Seed Production of Vegetable Crops) was successfully introduced and grown in several Russian regions. Our objective was to study the composition and content of low-molecular biologically active antioxidant metabolites that determine the nutritional and pharmacological value of amaranth leaves, and to assess the main antioxidant accumulation in plant organs under the conditions of the Moscow Region. For analysis, fresh and dried leaves (juvenile, those with a formed blade, and old ones), inflorescences, stems, veins, petioles and roots were used. Amaranthine, reduced ascorbic acid, and total antioxidant content was measured in water and ethanol extracts from fresh and dry leaves and plant organs. Also, simple phenols and oxybenzoic acids, flavonoids, condensed and polymeric polyphenols were assayed. Chlorogenic, gallic, ferulic acids and arbutin content was determined in aqueous extract by high performance liquid chromatography (HPLC). The metabolites were analyzed by gas chromatography-mass spectrometry (GC/MS). It was shown that actively photosynthesizing leaves with a fully formed blade predominantly accumulated ascorbic acid, while in the aging leaves its amount decreased. Veins, petioles and stems contained substantially less metabolites with antioxidant activity compared to leaves. In aqueous extracts, the main betacyanins were amaranthine and iso-amarantine. Chromatography of aqueous extracts from amaranth leaves showed the presence of highly active antioxidants, e.g. arbutin-glucoside hydroquinone and oxycinnamic acids including ferulic, chlorogenic, oxybenzoic (gallic) acids. In the tests, gallic acid concentration was $1.51 \mu \mathrm{g} / 100 \mathrm{ml}$, chlorogenic acid concentration was $2.05 \mu \mathrm{g} / 100 \mathrm{ml}$, ferulic acid concentration was $0.01 \mu \mathrm{g} / 100 \mathrm{ml}$, and arbutin concentration was $472.51 \mu \mathrm{g} / 100 \mathrm{ml}$. Water-extracted squalene $\left(\mathrm{C}_{30} \mathrm{H}_{50}\right)$, a powerful antioxidant usually isolated from amaranth seeds only, was first discovered in amaranth leaves. Ethanol extraction revealed a greater number of the colored components in the spectral range of the $350-700 \mathrm{~nm}$, in addition, gallic, chlorogenic and ferulic acids were found. A total of 37 low-molecular metabolites were identified by gas chromatography-mass spectrometry. Our findings indicate that vegetable amaranth, as a promising reproducible source of antioxidants, can be used in functional foods and phytobiologicals.
\end{abstract}

Keywords: amaranth, Amaranthus tricolor L., Valentina variety, low-molecular antioxidant metabolites, amaranthine, ascorbic acid, phenolic compounds

Amaranth (Amaranthus genus) is used in many countries as a grain, vegetable and medicinal crop. In Africa, the leaves of vegetable amaranth are used as an additional source of native protein which contains balanced essential 
amino acids [1]. Leaves and young plants of vegetable amaranth in Indonesia, China, India and South-East Asia are the main product that enriches foods with essential amino acids, biologically active substances and antioxidants [2, 3]. Preparations made of amaranth plants are widely used in phytomedicine to perform regulator and protective functions and to reduce the risk of chronic diseases caused by free radical oxidation [4].

In Russia, the use of vegetable species of amaranth with a high content of gluten-free protein and low-molecular antioxidants (e.g., vitamin $\mathrm{C}$, phenolic compounds, betalain pigments, and squalene) is relevant and necessary for compensation of essential nutrient deficiency. A detailed study of amaranth metabolites with antioxidant properties and a wide range of biological activity is necessary for the development and manufacture functional foods and beverages from amaranth leaves [5]. Vegetable amaranth species are also a valuable medicinal crop due to the high content of betacyanins, ascorbic acid, phenolic compounds and antioxidants of a different nature [6]. Antidiabetic [6-8], hepatoprotective [9, 10], gastroprotective [11], antitumor [12], and antimicrobial [13, 14] properties of the extracts from the leaves of Amaranthus tricolor L. have been proved.

Modern analytical methods such as mass spectrometry and high performance liquid chromatography (HPLC) allow identifying components that were not previously detected in assessing nutritional and pharmacological value of plant raw material, in order to develop innovative and biologically active plant preparations and products $[15,16]$.

This paper is the first report of identification of 37 metabolites with antioxidant properties form different classes of compounds (i.e., organic acids, sugars and their derivatives, phenols, triterpenes, amino acids) in the leaves of the Valentina variety vegetable amaranth. This widens using amaranth leaves for functional products with antistress activity.

The purpose of our study was to assess the qualitative composition of metabolites in aqueous and ethanolic amaranth extracts and to assess accumulation of the main antioxidant in plant organs under the conditions of the Moscow Region.

Techniqques. For study, we used fresh and dried leaves, inflorescences, stems, veins, petioles and roots of vegetable amaranth (Amaranthus tricolor L.) Valentina variety (originated by All-Russian Research Institute of Breeding and Seed Production of Vegetable Crops, VNIISSOK, Moscow Province), and also the biologically active additive Amarantil phytotea made of leaves of Valentina variety plants (VNIISSOK, Russia). Plants were grown in open experimental fields of VNIISSOC in 2015-2017. Laves of different ages (juvenile, those with a formed blade, and old ones) were used. Fresh material was placed in a homogenizer; samples were prepared in accordance with the methods intended for each special study. The dried samples were crushed in a mill up to 1-2 mm size. Aqueous and ethanolic extracts of fresh and dried plant material were used.

The amaranthine in aqueous extracts was quantified using molar extinction coefficient $5.66 \times 10^{4} \mathrm{l} / \mathrm{mole}^{-1} \cdot \mathrm{cm}^{-1}$ and a molar weight of 726.6 $\mathrm{g} / \mathrm{mole}^{-1}$ [17]. The concentration of reduced ascorbic acid (AA) was evaluated by iodometric method based on the AA titration in extracts stained with potassium iodate under acidic conditions in the presence of potassium iodide and starch [18]. The total antioxidants (TA) in aqueous and ethanolic extracts were determined amperometrically [19]; the result was expressed via gallic acid equivalents (mg-equivalent GA/g).

The samples were crushed in a homogenizer in the presence of extracting liquids (bidistilled water or $96 \%$ ethyl alcohol) at $20-25{ }^{\circ} \mathrm{C}$. The homogenates were centrifuged for 15 minutes at $10,000 \mathrm{~g}$ and $4{ }^{\circ} \mathrm{C}$. An aliquot of the superna- 
tant was used to determine the antioxidant content after dilution, if necessary. The measurements were carried out on a Tsvet-Yauza 01-AA (NPO Khimavtomatika, Russia) in a constant current mode.

The content of simple phenols and oxybenzoic acids, oxycinnamic acids and their esters, flavonoids, condensed and polymeric polyphenols was determined in the fractions of dry inflorescences, leaves and stems [20].

Spectral characteristics were measured using a Helios Gamma spectrophotometer (Thermo Electron Corporation, USA) at $\lambda=200-600 \mathrm{~nm}$. The amount of chlorogenic, gallic, ferulic acids and arbutin in the aqueous extract from Amarantil phytotea was determined by high performance liquid chromatography (HPLC) with a liquid chromatograph KNAUER (KNAUER Wissenschaftliche Gerдte GmbH, Germany). A $150 \mathrm{~mm}$ column with a reversed phase was filled with sorbent Diasfer 110-S18 (Russia) with a grain size of $5 \mu \mathrm{m}$, the mixture of $0.03 \%$ trifluoroacetic acid:acetonitrile (70:30) served as the eluent. Peaks were identified by the retention time; the content of individual substances was determined using calibration solutions. The qualitative analysis of metabolites was performed by gas chromatography mass-spectrometry (GC/MS) with a chromatograph JMS-Q1050GC (JEOL Ltd., Japan). A capillary column DB5HT was used (Agilent, US; $30 \mathrm{~m}$ in length, inner diameter of $0.25 \mathrm{~mm}$, film thickness $0.52 \mu \mathrm{m}$, with helium as a carrier gas). The temperature gradient ranged from 40 to $300{ }^{\circ} \mathrm{C}$, with the injector and interface temperature of $280{ }^{\circ} \mathrm{C}$, and the of ion source temperature of $200{ }^{\circ} \mathrm{C}$; the gas flow rate in the column was $2.0 \mathrm{ml} / \mathrm{min}$. The time for analysis was $45 \mathrm{~min}$ ubder the flow division input mode and a $1 \mu \mathrm{l}$ sample introduced. To determine the substances, derivatization with silylation agent N,O-bis(trimethylsilyl) trifluoroacetamide (BSTFA) [21] was performed. The substance identification was based on the retention time and mass spectra indicated in the NIST-5 library of the National Institute of Standards and Technology (USA). The scanning range was 33-900 m/z.

All measurements were carried out in three replications; the tables show the mean values $(X)$ and their standard deviations $( \pm x)$.

Results. A specific feature of the leaves of $A$. tricolor L. Valentina plants is the red coloration of different intensity which depends on a eaf age and is determined by the amount of the amaranthine pigment found in all the studied plant organs (leaves, roots, petioles, stems, inflorescences). The aqueous extracts from leaves of different ages differed in the amount of the main metabolites with antioxidant properties, i.e., amaranthine, ascorbic acid, and carotenoids (Table 1). Juvenile leaves accumulated the maximum amount of amaranthine the content of which decreased with the growth and aging of the leaf blade. Ascorbic acid was predominantly accumulated in actively photosynthetic leaves with a fully formed blade; in the aging leaves its amount decreased. In juvenile leaves, there was also a tendency towards an increase in the content of ascorbic acid.

Since the organs of amaranth plants differ in antioxidant levels, the total content of antioxidants [19] can be used as an integral parameter to analyze the pattern of their combined change. In the leaves with an unformed blade, the content was lower than that in the leaves with a fully formed blade. At the same time, veins, petioles, and stems accumulated significantly less metabolites with antioxidant activity compared to the leaves.

Among the secondary metabolites synthesized in vegetable plants a group of aromatic phenolic compounds [13] was specified by the biological activity. We have found that simple phenols such as oxybenzoic and oxycinnamic acids and their esters, flavonoids, polymeric and condensed polyphenols are widespread in the leaves and fruits of vegetable and spicy plants [20,21]. The role of secondary metabolites in plants is still poorly understood. It is known that they determine the 
medicinal and toxic properties, participate in protection from biotic stressors, and also in the interactions of plants with each other and with other organisms, are involved in reproduction via color, smell of flowers and fruits [22]. In the leaves of amaranth plant, a significant proportion of phenolic compounds were flavonoids (Table 2).

1. Content of antioxidant metabolites in the organs of amaranth (Amaranthus tricolor L.) Valentina plants $(X \pm x$, All-Russian Research Institute of Breeding and Seed Production of Vegetable Crops, Moscow Region, 2015)

\begin{tabular}{|c|c|c|c|c|}
\hline \multirow[b]{2}{*}{ Organ } & \multirow{2}{*}{$\begin{array}{l}\text { Leaf number } \\
\text { (from the bottom } \\
\text { upwards) }\end{array}$} & \multicolumn{2}{|c|}{ Содержание } & \multirow{2}{*}{$\begin{array}{l}\text { Total antioxidants, } \\
\text { mg-equivalent GA/g } \\
\text { wet weight }\end{array}$} \\
\hline & & $\begin{array}{l}\text { ascorbic } \\
\text { acid, } \mathrm{mg} \%\end{array}$ & $\begin{array}{l}\text { amaranthine, mg/g } \\
\text { wet weight }\end{array}$ & \\
\hline \multirow[t]{3}{*}{ Old leaves } & 1 & $161 \pm 15.0$ & $0.26 \pm 0.02$ & $2.32 \pm 0.11$ \\
\hline & 2 & $186 \pm 15.0$ & $0.29 \pm 0.02$ & $2.30 \pm 0.11$ \\
\hline & 3 & $176 \pm 15.0$ & $0.44 \pm 0.05$ & $2.25 \pm 0.11$ \\
\hline \multirow[t]{3}{*}{ Leaves with a formed blade } & 4 & $230 \pm 15.0$ & $0.48 \pm 0.05$ & $2.26 \pm 0.11$ \\
\hline & 5 & $202 \pm 15.0$ & $0.51 \pm 0.05$ & $2.20 \pm 0.11$ \\
\hline & 6 & $216 \pm 15.0$ & $0.57 \pm 0.05$ & $2.21 \pm 0.11$ \\
\hline Leaves with an unformed & 7 & $149 \pm 15.0$ & $0.55 \pm 0.05$ & $1.81 \pm 0.10$ \\
\hline \multirow[t]{2}{*}{ blade and juvenile } & $\begin{array}{l}8 \\
9\end{array}$ & $133 \pm 15.0$ & $0.72 \pm 0.05$ & $2.00 \pm 0.11$ \\
\hline & $\begin{array}{l}10 \\
11\end{array}$ & $167 \pm 15.0$ & $0.94 \pm 0.05$ & $2.11 \pm 0.11$ \\
\hline Leaf vein & & & $0.31 \pm 0.02$ & $0.70 \pm 0.04$ \\
\hline Leaf petioles & & $17 \pm 1.5$ & $0.79 \pm 0.05$ & $0.69 \pm 0.04$ \\
\hline Stem & & $10 \pm 1.5$ & $0.21 \pm 0.02$ & $0.43 \pm 0.03$ \\
\hline Inflorescence & & $130 \pm 15.0$ & $0.75 \pm 0.05$ & $1.18 \pm 0.05$ \\
\hline Roots & & $10 \pm 1.5$ & $0.11 \pm 0.02$ & $0.45 \pm 0.03$ \\
\hline
\end{tabular}

2. Phenolic compounds ( $\mathrm{PhC}, \%$ per absolute dry weight) in inflorescences, leaves and stems of the amaranth (Amaranthus tricolor L.) Valentina plants ( $X \pm x$, AllRussian Research Institute of Breeding and Seed Production of Vegetable Crops, Moscow Province, 2015)

\begin{tabular}{l|c|c|c|c|c}
\hline Organ & PhC sum & $\begin{array}{l}\text { Simple phenolic } \\
\text { compounds and hy- } \\
\text { droxybenzoic acids }\end{array}$ & $\begin{array}{l}\text { Hydroxycinnamic } \\
\text { acids and their } \\
\text { ethers }\end{array}$ & Flavonoids & $\begin{array}{l}\text { Condensed and } \\
\text { polymeric PhC }\end{array}$ \\
\hline Inflorescence & 5.52 & $0.55 \pm 0.05$ & $0.09 \pm 0.01$ & $3.94 \pm 0.11$ & $0.94 \pm 0.11$ \\
Leaves & 5.47 & $0.43 \pm 0.05$ & $0.09 \pm 0.01$ & $4.21 \pm 0.11$ & $0.74 \pm 0.11$ \\
Stem & 3.23 & $0.32 \pm 0.05$ & $0.05 \pm 0.01$ & $0.52 \pm 0.11$ & $2.34 \pm 0.11$ \\
\hline
\end{tabular}

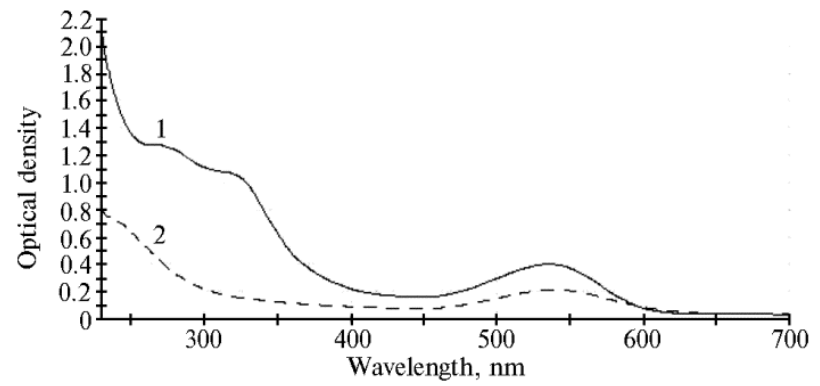

Fig. 1. Absorption of aqueous extracts from the leaves of amaranth (Amaranthus tricolor L.) Valentina variety: 1 - Amarantil phytotea, 2 - amaranthine (All-Russian Research Institute of Breeding and Seed Production of Vegetable Crops, Moscow Province, 2016). ranth leaves, we found the following physiologically active substances with antioxidative activity: amaranthine, ascorbic acid, flavonoids, simple phenols and phenolcarbonic acids.

Spectrum of the extract from the biologically active food Amarantil phytotea exhibited three absorption maxima at 250-270, 325 and $540 \mathrm{~nm}$ (Fig. 1), 
which indicates the presence of components of phenolic nature. One of the maxima $(\lambda=540 \mathrm{~nm})$ coincided with the maxima for the amaranthine pigment extracted from the leaves.

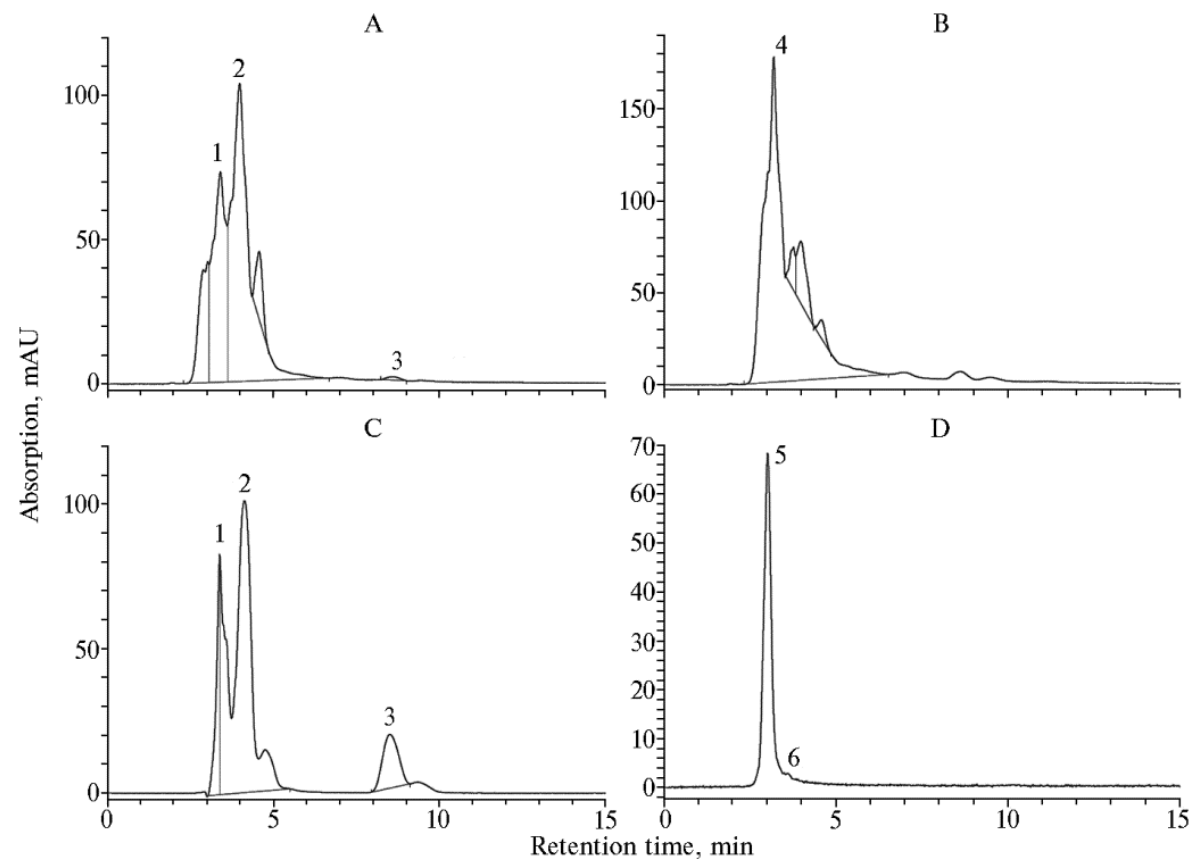

Fig. 2. Chromatographic profiles of water extract from amaranth (Amaranthus tricolor L.) Valentina leaves (Amarantil" phytotea) $(\lambda=325 \mathrm{~nm})(\mathrm{A})$, gallic acid standard $(\lambda=268 \mathrm{~nm})(\mathrm{B})$, standard mixture of arbutin, chlorogenic and ferulic acids $(\lambda=325 \mathrm{~nm})(C)$, amaranthine pigment $(\lambda=540 \mathrm{~nm})$ (D): 1 - arbutin, 2 - chlorogenic acid, 3 - ferulic acid, 4 - gallic acid, 5 - amaranthine, $6-$ isoamaranthine (All-Russian Research Institute of Breeding and Seed Production of Vegetable Crops, Moscow Province, 2017). Liquid chromatograph KNAUER (Germany).

In chromatographic analysis, phenolic compounds in an aqueous extract of amaranth leaves (Amarantil phytotea) were detected at 268 and $325 \mathrm{~nm}$. In the fresh amaranth leaves, chlorogenic, ferulic, gallic acid and arbutin were found $(2.05 \pm 0.10,0.01,1.51 \pm 0.04$ and $473 \pm 20 \mathrm{~g} / \mathrm{ml}$, respectively), as well as unidentified compounds with retention time $4-8 \mathrm{~min}$ (Fig. 2, A, C). V.B. Gopal et al. [23] found gallic and ferulic acids in an amount of 0.083 and $0.001 \mu \mathrm{g} / \mathrm{ml}$ in an aqueous extract of amaranth leaves. Gallic acid was analyzed at $\lambda=268 \mathrm{~nm}$, and

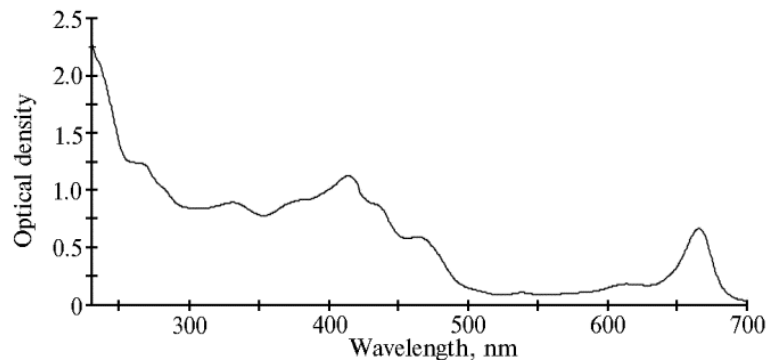

Fig. 3. Absorption ethanolic extract of amaranth (Amaranthus tricolor L.) Valentina leaves (All-Russian Research Institute of Breeding and Seed Production of Vegetable Crops, Moscow Province, 2017). chlorophyll. Its spectrum was significantly different from the spectrum of the water extract, especially at 350-500 $\mathrm{nm}$ and $600-700 \mathrm{~nm}$ (Fig. 3). In the range of 250$300 \mathrm{~nm}$, the water and ethanolic extract spectra were similar. $\lambda=540 \mathrm{~nm}$. For the red pigment absorption, two components were determined, amaranthine and its isomer isoamaranthine (Fig. 2, D). The spectra of amaranthine detected by the HPLC method and the pigment standard completely coincided.

The ethanolic extract of amaranth leaves had an intense green color due to the extracted

red pigment was analyzed at

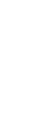


Consequently, more colored components were extracted from the leaves by the ethanol. The chromatographic analysis of the ethanolic extract of amaranth leaves at 268 and $325 \mathrm{~nm}$ was also carried out with gallic, chlorogenic and ferulic acids detected (Fig. 4). With a minimum of absorption (see Fig. 3, $\lambda=540 \mathrm{~nm}$ ), only the solvent peak was detected.

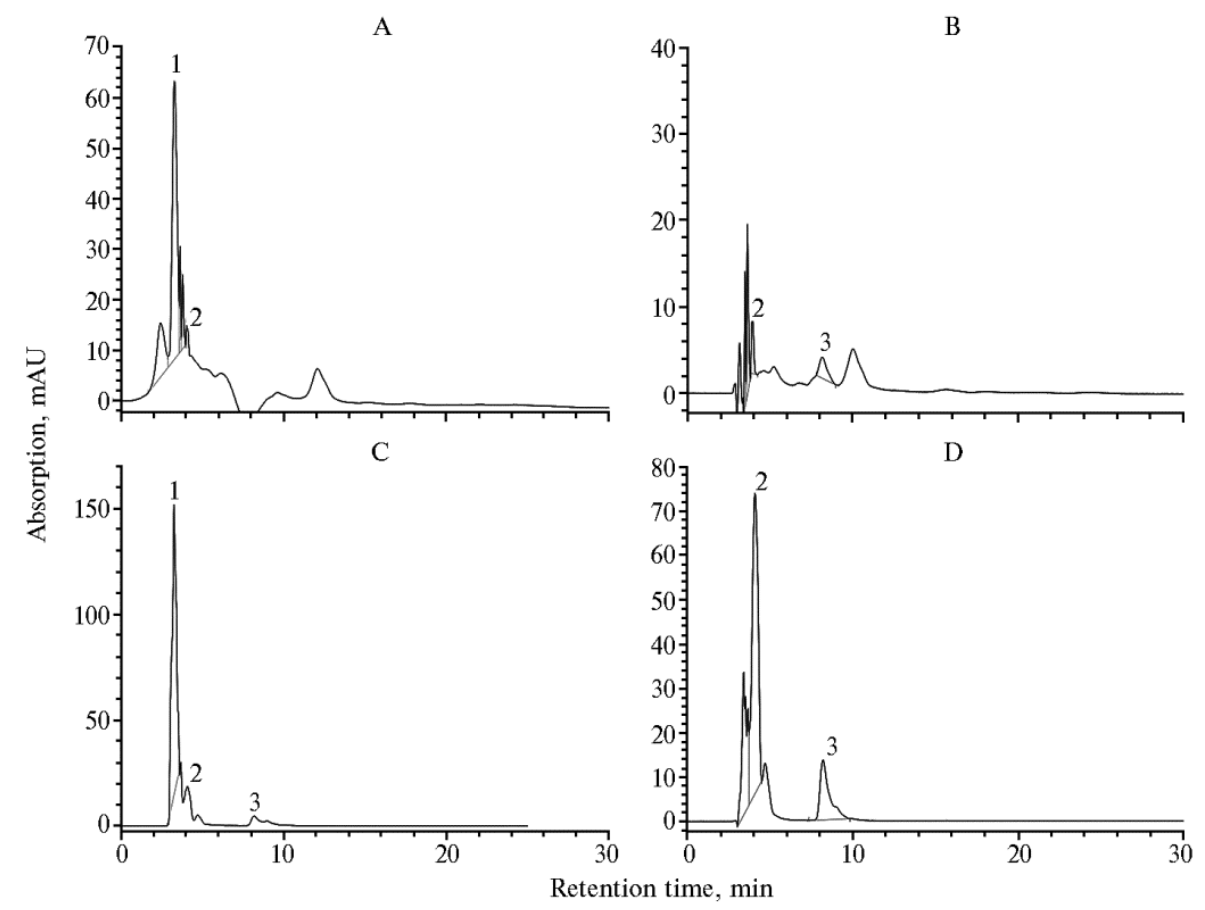

Fig. 4. Chromatographic profiles of the extract of amaranth (Amaranthus tricolor L.) Valentina leaves for the analyzed sample $(A, B)$ and standard mixture $(B, D)$ at $\lambda=268 \mathrm{~nm}(A, C)$ and $\lambda=325 \mathrm{~nm}$ (B, D): 1 - gallic acid, 2 - chlorogenic acid, 3 - ferulic acid (All-Russian Research Institute of Breeding and Seed Production of Vegetable Crops, Moscow Province, 2016) Liquid chromatograph KNAUER (Germany).

Our data on phenolic compounds in the A. tricolor leaves broaden the idea about nutritive and medicinal low-molecular metabolites in amaranth plants and can supplement the information available in the scientific literature. All metabolites identified by HPLC are biologically active substances that exhibit antioxidant activity. Phenolic acids and betacyanin (amaranthine) are characterized by antibacterial [13, 14], antimycotic, anti-inflammatory, and wound-healing properties [23]. Ferulic acid possesses radioprotective properties [24], glycosylated hydroquinone arbutin exhibits antioxidant activity [25].

The results of qualitative GC/MS analysis of water and ethanolic extracts from amaranth leaves are illustrated in Fig. 5.

The chromatograms clearly show the qualitative differences between the extracts in composition. More than 30 individual substances (15 in aqueous extract and 19 in ethanolic extract) representing different classes of chemical compounds (Table 1) were identified based on the library mass spectra (Table 3).

In the extracts of $A$. tricolor leaves, six organic acids were found: valerian and cinnamic acids in aqueous extract, amber, propene, methylmalonic and ribonic acids in ethanolic extract. Five saturated fatty acids were found: myristic $\left(\mathrm{C}_{13: 0}\right)$, palmitic $\left(\mathrm{C}_{15: 0}\right)$, margarine $\left(\mathrm{C}_{15: 0}\right)$ and stearic $\left(\mathrm{C}_{17: 0}\right)$ for the aqueous extract, and palmitic $\left(\mathrm{C}_{15: 0}\right)$ and lignoceric $\left(\mathrm{C}_{23: 0}\right)$ for ethanolic in the aqueous extract. Fatty acids have bactericidal, antiviral and fungicidal activity leading to suppression of pathogenic microflora and yeast fungi. Among unsaponifiable li- 
pids, there are bioactive phytosterols. It is known that squalene $\left(\mathrm{C}_{30} \mathrm{H}_{50}\right)$ is a unique phytosterol of amaranth seed, which participates in the synthesis of cholesterol as its precursor [26] and also in the synthesis of an active antioxidant with anticarcinogenic and wound-healing effect. An adequate amount of squalene consumption is $400 \mathrm{mg}$ per day. Squalene is a precursor of a number of valuable pharmacological substances: cardiac glycosides, glycoalkaloids, and saponins. Squalene, first discovered by us in the aqueous extract of amaranth leaves of the Valentina variety, improves their pharmacological value.

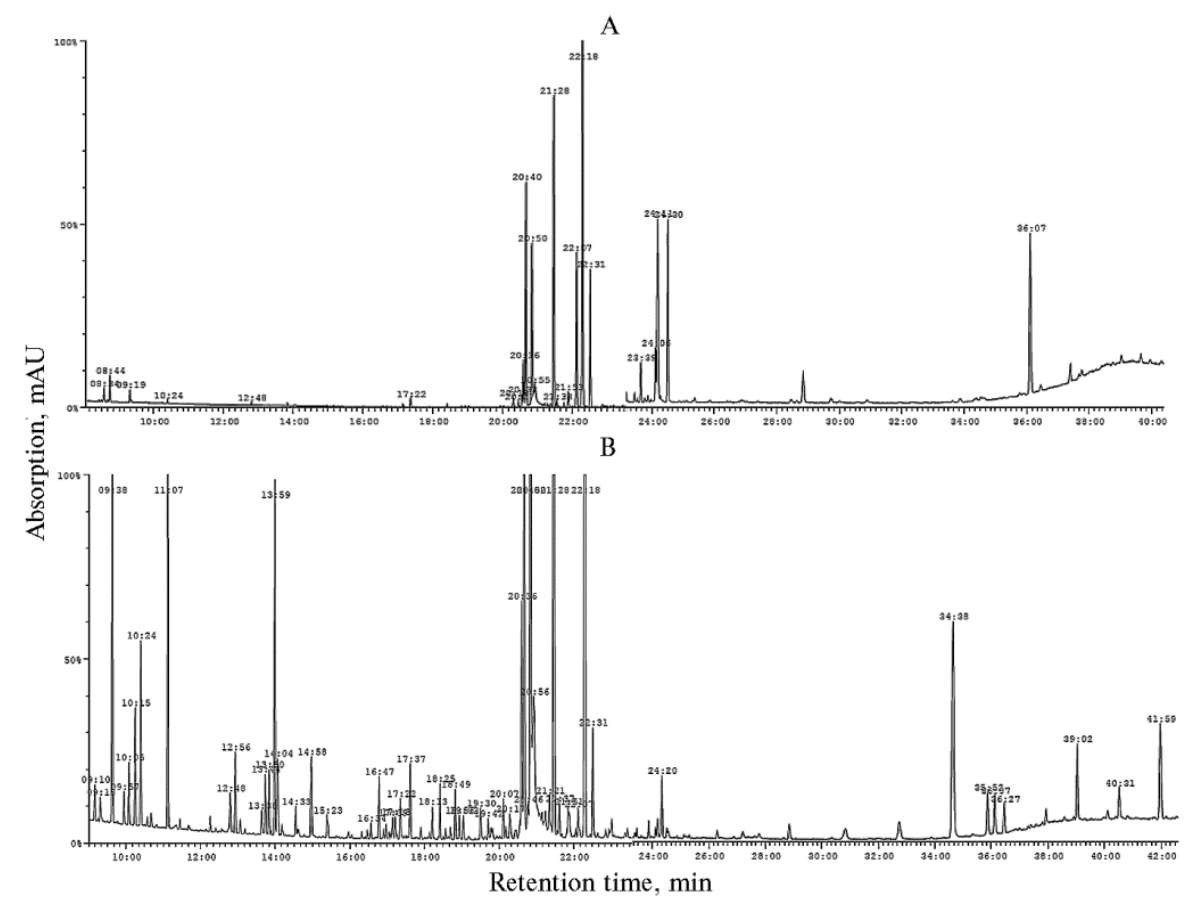

Fig. 5. Fragments of the mass spectra of water (A) and ethanol (B) extracts of amaranth (Amaranthus tricolor L.) Valentina leaves (All-Russian Research Institute of Breeding and Seed Production of Vegetable Crops, Moscow Province, 2017). Gas chromatography mass spectrometer JMS-Q1050GC (JEOL Ltd., Japan).

In the aqueous fraction of extracts we identified five carbohydrates: monosaccharides of galactose and mannose, cyclic forms (galactopyranose and fructofuranose) and ketohexose tagatose. In the ethanolic extract, we identified seven carbohydrates and their cyclic forms, a sugar derivative (gluconic acid) and two hexatomic alcohols (inositol and mannitol). Polyatomic alcohols exhibit cryo- and osmoprotective properties in the cell.

3. Metabolites discovered in aqueous and ethanol extracts of amaranth (Amaranthus tricolor L.) Valentina leaves by gas chromatography mass-spectrometry (AllRussian Research Institute of Breeding and Seed Production of Vegetable Crops, Moscow Province, 2017)

\begin{tabular}{ll|c}
\hline \multicolumn{1}{c|}{ Rt, min } & \multicolumn{1}{c}{ Compound } & Extract \\
\hline & & \\
$22: 07$ & Propenoic acid, Acrylic acid, $\mathrm{C}_{3} \mathrm{H}_{4} \mathrm{O}_{2}$ & a c i s s \\
$14: 04$ & Succinic acid, $\mathrm{C}_{4} \mathrm{H}_{4} \mathrm{O}_{4}$ & $\mathrm{C}$ \\
$16: 34$ & Monoamidoethyl malonic acid, $\mathrm{C}_{4} \mathrm{H}_{6} \mathrm{O}_{4}$ & $\mathrm{C}$ \\
$20: 47$ & Pentanoic acid, $\mathrm{CH}_{3}\left(\mathrm{CH}_{2}\right) \mathrm{COOH}$ & B \\
$22: 41$ & Ribonic acid, $\mathrm{C}_{5} \mathrm{H}_{10} \mathrm{O}_{5}$ & $\mathrm{C}$ \\
$22: 51$ & Cinnamic acid (Isoferulic acid), $\mathrm{C}_{9} \mathrm{H}_{8} \mathrm{O}_{2}$ & B a t y a c d s \\
$17: 51$ & Octadecanoic $\left(\mathrm{Stearic}_{2}\right.$ acid, $\mathrm{C}_{17} \mathrm{H}_{35} \mathrm{COOH}$ & \\
$19: 07$ & Myristic acid, $\mathrm{C}_{13} \mathrm{H}_{27} \mathrm{COOH}$ & B \\
$23: 11$ & Margaric acid, Heptadecanoic acid, $\mathrm{C}_{16} \mathrm{H}_{33} \mathrm{COOH}$ & B \\
$21: 15$ & Palmitic acid, Hexadecanoic acid, $\mathrm{C}_{15} \mathrm{H}_{31} \mathrm{COOH}$ & B
\end{tabular}


Fructofuranose, D-(-)-Fructopyranose, $\mathrm{C}_{5} \mathrm{H}_{8} \mathrm{O}_{6}$

Glucofuranose, $\mathrm{C}_{6} \mathrm{H}_{6} \mathrm{O}_{6}$

Talose, D-(+)-Talofuranose, $\mathrm{C}_{5} \mathrm{H}_{12} \mathrm{O}_{6}$

Mannose, D-Mannopyranose, $\mathrm{C}_{6} \mathrm{H}_{12} \mathrm{O}_{6}$

22:17
S ug a r derivatives e

$\mathrm{N}$ o t e. $\mathrm{Rt}-$ retention time, $\mathrm{B}-$ aqueous extract, $\mathrm{C}-$ ethanolic extract.

In the literature, there is evidence that simple sugars and their derivatives (alcohols, lactones), when accumulating in cells, are capable of performing protective functions under the action of stress factors. Glucose, fructose, mannose, mannit, inositol and galactose exhibit antioxidant properties in cells at low temperatures. The protective effect of simple sugars is due to their ability to bind free radicals non-specifically, to prevent the development of lipid peroxidation and to inactivate reactive oxygen species [27-30].

In our experiments, the ethanolic extract of leaves of the A. tricolor Valentina variety contained vitamin $\mathrm{E}$, which is the universal protector of cell membranes from oxidative damage, shows neuroprotective, antioxidant properties and reduces the risk of cancer. Micromolar amounts of vitamin E reduce the activity of 3-hydroxy-3-methylglutaryl-CoA-reductase, responsible for the synthesis of cholesterol, thus reducing cholesterol level in the body [31].

Thus, a comprehensive analysis of the metabolites in the leaves of amaranth (Amaranthus tricolor L.) Valentina variety showed the presence of powerful antioxidants - squalene, which was previously found in seeds only, ascorbic acid, the content of which is comparable to that of pepper, gallic, ferulic and chlorogenic acids, sugars and their derivatives, triterpenes, betacyanins with antioxidant activity. The pharmacological value of the identified metabolites is due to their ability to reduce the risk of developing pathologies with a free-radical component (cardiovascular, oncological, diabetes, etc.), which makes it possible to use these natural compounds in antioxidant therapy as anti-stressors. The high content of such metabolites in Valentina variety, their nutritive and pharmacological value, makes this variety promising for use in food industry and medicinal technologies to develop non-toxic antioxidant food additives, functional products (teas, natural pigments, non-alcoholic vitamin drinks, confectionery fillings) and phytobiologicals using leaves and leaf extracts.

\section{R E F E R E N C ES}

1. B e r b e ri c h S. History of amaranth. Agriculture Research, 1980, 29(4): 14.

2. Z h e le z n o v A.V. Khimiya $i$ zhizn', 2005, 6: 56-61 (in Russ.).

3. Rast ogi A., Shukla S. Amaranthus: a new millennium crop of nutraceutical values. Critical reviews in food science and nutrition. Critical Reviews in Food Science and Nutrition, 2013, 
53: 109-125 (doi: 10.1080/10408398.2010.517876).

4. B aral M., Datta A., Chakraborty S., Chakraborty P. Pharmacognostic studies on stem and leaves of Amaranthus spinosus Linn. International Journal of Applied Biology and Pharmaceutical Technology, 2011, 2: 41-47.

5. Gins M.S., Gins V.K., Pivovarov V.F., Kononkov P.F., D e rkanos o v a N.M. Vestnik rossiiskoi sel'skokhozyaistvennoi nauki, 2017, 2: 3-5 (in Russ.).

6. Kavita P., Pun e et G. Rediscovering the therapeutic potential of Amaranthus species: a review. Egyptian Journal of Basic and Applied Sciences, 2017, 4: 196-205 (doi: 10.1016/j.ejbas.2017.05.001).

7. Rahmatullah M., Hosain M., Rahman S., Akter M., Rahman F., Re hana F., Munmun M., Kalpana M.A. Antihyperglycemic and antinociceptive activity evaluation of methanolic extract of whole plant of Amaranthus tricolor L. (Amaranthaceae). African Journal of Traditional, Complementary and Alternative Medicines, 2013, 408(10): 11.

8. Clemente A.C., Desai P.V. Evaluation of the hematological, hypoglycemic, hypolipidemic and antioxidant properties of Amaranthus tricolor leaf extract in Rat. Tropical Journal of Pharmaceutical Research, 2011, 10: 595-602.

9. Al-D os a ri M.S. The effectiveness of ethanolic extract of Amaranthus tricolor L.: a natural hepatoprotective agent. The American Journal of Chinese Medicine, 2010, 38: 1051-1064 (doi: 10.1142/S0192415X10008469).

10. Aneja S., Vats M., Aggarwal S., S a rda na S. Phytochemistry and hepatoprotective activity of aqueous extract of Amaranthus tricolor Linn. roots. Journal of Ayurveda and Integrative Medicine, 2013, 4(4): 211-215 (doi: 10.4103/0975-9476.123693).

11. Devaraj V.C., Krishna B.G. Gastric antisecretory and cytoprotective effects of leaf extracts of Amaranthus tricolor Linn. in rats. Zhong Xi Yi Jie He Xue Bao, 2011, 9(9): 1031-1038.

12. Gins M.S., B odyagin D.A., Ko nonkov P.F., I s a kova E.B., Gins V.K., B u k h m a n V.M. Protivoopukholevoe sredstvo. Patent RU 2377008 C2. VNIISSOK (RF). Zayavl. 18.12.2007. Opubl. 27.12.2009. Byul. № 36 [Antitumor agent. Patent RU 2377008 C2. VNIISSOK (RF). Appl. December 18, 2007. Publ. December 27, 2009. Bul. № 36] (in Russ.).

13. Tharun Rao K.N., Padhy S.K., Dinakaran S.K., Banji D., Avasarala H., Ghosh S., Pras ad M.S. Pharmacognostic, phytochemical, antimicrobial and antioxidant activity evaluation of Amaranthus tricolor Linn. leaf. Asian Journal of Chemistry, 2012, 24(1): 455-460.

14. Pulipati S., B abu P.S., N a ras u M.L. Quantitative determination of tannin content and evaluation of antibacterial activity of Amaranthus tricolor (L). International Journal of Biological \& Pharmaceutical Research, 2014, 5(7): 623-626.

15. L ok hov P.G., A c hak ov A.I. Biomeditsinskaya khimiya, 2008, 54(5): 497-511 (in Russ.).

16. S o s i pat rova A.A., O s i pov V.I., D e mina I.B., B y k ov V.A. Voprosy biologicheskoi, meditsinskoi i farmatsevticheskoi khimii, 2011, 3: 23-29 (in Russ.).

17. B i s w a s M., D e y S., S e n R. Betalains from Amaranthus tricolor L. Journal of Pharmacognosy and Phytochemistry, 2013, 1(5): 87-95.

18. Sapozhnikov A.B. Trudy Mordovskogo gosudarstvennogo universiteta, 1966, 55-57 (in Russ.).

19. Gins M.S., Gins V.K., Kononkov P.F., Baikov A.A., Torres M.K., Roma no v a E.V., L a p o O.A. Metodika analiza summarnogo soderzhaniya antioksidantov $v$ listovykh $i$ listostebel'nykh ovoshchnykh kul'tur [Analysis of total antioxidants in leaf and leaf stem vegetables]. Moscow, 2013 (in Russ.).

20. Gins M.S., Gins V.K., Kolesnikov M.P., Kononkov P.F., Chekmarev P.A., Kagan M.Yu. Metodika analiza fenol'nykh soedinenii $v$ ovoshchnykh kul'turakh [Analysis of phenolic compouds in vegetable crops]. Moscow, 2010 (in Russ.).

21. Robbins R.J. Phenolic acids in foods: an overview of analytical methodology. Journal of Agricultural and Food Chemistry, 2003, 51: 2866-2887 (doi: 10.1021/jf026182t).

22. Koles nik ov M.P., G i n s V.K. Prikladnaya biokhimiya i mikrobiologiya, 2001, 37(4): 457465 (in Russ.).

23. B i a n i G.V., B odha $\mathrm{nk}$ a r S.L., K a d a m P., Z a m b a re G.N. Anti-nociceptive and anti-inflammatory activity of hydroalcoholic extract of leaves of Amaranthus tricolor L. Scholars Research Library, Der Pharmacia Lettre, 2013, 5(3): 48-55.

24. $\mathrm{A} b$ i s a $1 \mathrm{ov}$ a I.L., $\mathrm{N}$ a $\mathrm{z}$ a r o v a L.E., O g u r t s o v Yu.A. Radioprotektornye svoistva ferulovoi kisloty [Radioprotective effect of ferulic acid]. Pyatigorsk, 2003 (in Russ.).

25. Shkarina E.I., Maksimova T.V., Lozovskaya E.A., Chumakova Z.V., Pak ho mov V.P., S a p e $\mathrm{z}$ h i n s ki i I.I., Arza m a s t s e A.P. Khimiko-farmatsevticheskii zhurnal, 2001, 35(6): 40-47 (in Russ.).

26. Shmal'ko N.A., Roslyakov Yu.F. Amarant $v$ pishchevoi promyshlennosti [Amaranth in food industry]. Krasnodar, 2011 (in Russ.).

27. Ave r'y a nov A.A., La p i k o v a V.P. Biokhimiya, 1989, 54: 1646-1651 (in Russ.).

28. S in'kevich M.S., Deryabin A.N., Trunova T.I. Fiziologiya rastenii, 2009, 56(2): 186-192 (in Russ.). 
29. Sin'kevich M.S., Sabel'nikova E.P., Deryabin A.N., Astakhova N.V., Dubinina I.M., Burokhanova E.A., Tru nova T.I. Fiziologiya rastenii, 2008, 55(4): 501-506 (in Russ.).

30. Morelli R., Rus so-Volpe S., Bruno N., Lo Scalzo R. Fenton-depended damage to carbohydrates: free radical scavenging activity of some simple sugars. Journal of Agricultural and Food Chemistry, 2003, 51: 7418-7425.

31. Ch a nd a n K.S., S a vit a K., S a s hw at i R. Tocotrienols: vitamin E beyond tocopherols. Life Sciences, 2006, 78(18): 2088-2098 (doi: 10.1016/j.lfs.2005.12.001). 